\title{
Relationship between mineralized nitrogen during anaerobic incubations and residual effect of nitrogen fertilization in two rice paddy soils in Chile
}

\author{
Diego Villaseñor ${ }^{1}$, Erick Zagal ${ }^{1}$, Neal Stolpe ${ }^{1}$, and Juan Hirzel ${ }^{2 *}$
}

An important $\mathrm{N}$ source for rice (Oryza sativa L.) is mineralization of the organic forms of $\mathrm{N}$ present in the soil. The correct $\mathrm{N}$ determination will help to optimize the amount of fertilizer used. Our objective was to calculate an index that relates crop $\mathrm{N}$ uptake from previous $\mathrm{N}$ fertilization and $\mathrm{N}$ mineralized in rice paddy soils. To do so, we used two rice paddy soils, Alfisol and Vertisol, in Chile under different anaerobic incubation times and temperatures. We determined both soil mineralization and residual effect of fertilization in the previous season under field and laboratory conditions in an Alfisol and a Vertisol managed with a rice monocrop. Anaerobic incubations were carried out at 20 and $40{ }^{\circ} \mathrm{C}$; and at five different times $(0,7,14$, 21 , and $28 \mathrm{~d}$ ). Our results indicate that residual fertilization affects $\mathrm{N}$ mineralization, which increases in both paddy soils when compared with the control without N. In the Alfisol it fluctuates between 6.1 and $13.3 \mathrm{mg} \mathrm{N}-\mathrm{NH}_{4}{ }^{+} \mathrm{kg}^{-1}$, whereas in the Vertisol ranged between 18.4 and $28.0 \mathrm{mg} \mathrm{N}^{-\mathrm{NH}_{4}}{ }^{+} \mathrm{kg}^{-1}$. Crop $\mathrm{N}$ uptake as a residual effect of applied $\mathrm{N}$ ranged between 29.3 and $33.9 \mathrm{~kg} \mathrm{~N}^{-1}$ in the Alfisol and 28.3 and $45.8 \mathrm{~kg} \mathrm{~N} \mathrm{ha}^{-1}$ in the Vertisol. Thus, $\mathrm{N}$ mineralization is mainly affected by incubation time, temperature, and $\mathrm{N}$ fertilization rate of the previous crop season; it can be represented by quadratic models with high determination values, $\mathrm{R}^{2}=0.73^{* *}$ and $\mathrm{R}^{2}=0.78^{* *}$, for Alfisol and Vertisol, respectively. Moreover, we found that the best incubation time and temperature were $7 \mathrm{~d}$ at $20{ }^{\circ} \mathrm{C}$ and $21 \mathrm{~d}$ at $40{ }^{\circ} \mathrm{C}$, for the Altisol and Vertisol, respectively. In addition, there are potential savings in the next rice crop season from 0.86 to $0.43 \mathrm{~kg} \mathrm{~N}$ applied for each 1 mg N kg-1 mineralized in the Alfisol and Vertisol, respectively. We conclude that crop $\mathrm{N}$ uptake was related to mineralized $\mathrm{N}$ and that the equation here developed that relates them is a good predictor to optimize fertilizer use in rice paddy fields.

Key words: Residual effect, fertilization, nitrogen, Oryza sativa.

\section{INTRODUCTION}

Rice (Oryza sativa L.) crop management in Chile leads to soil $\mathrm{N}$ accumulation (Hirzel et al., 2012). The measurement or determination of this accumulated $\mathrm{N}$ will help to optimize the use of $\mathrm{N}$ fertilizers (Sainz et al., 2004). While the area under rice cultivation in the world is approximately 147.5 million ha, the estimated area in Chile is 21000 ha (ODEPA, 2013), which is concentrated in the Central valley (34-36 $\mathrm{S}$ lat) (Alvarado and Hernaiz, 2007). Rice paddy soils in Chile correspond to Alfisol, Vertisol, and Inceptisol orders (CIREN, 1983). Rice productivity depends on several factors: climate, soil physical condition and fertility, water supply, sowing date, variety, seed rate, weed control, and fertilization (Jing et al., 2008); the later factors affecting $\mathrm{N}$ mineralization.

Nitrogen mineralization is a fundamental process to further supplement $\mathrm{N}$ to the crops (Honeycutt, 1999).

${ }^{1}$ Universidad de Concepción, Facultad de Agronomía, Av. Vicente Méndez 595, Chillán, Chile.

${ }^{2}$ Instituto de Investigaciones Agropecuarias, INIA Quilamapu, Av. Vicente Méndez 515, Chillán, Chile.

*Corresponding author (jhirzel@inia.cl).

Received: 10 March 2014.

Accepted: 24 October 2014.

doi:10.4067/S0718-58392015000100014
The accurate estimation of $\mathrm{N}$ to optimize fertilizer use is critic. Moreover, since $\mathrm{N}$ absorbed by the plant is mainly from reserves generated by organic matter mineralization, microbial biomass activity, fixed $\mathrm{N}^{-\mathrm{NH}_{4}}{ }^{+}$in clay (Sainz et al., 2004; Sahrawat, 2006), and fertilization (Wienhold, 2007). However, accurate prediction of $\mathrm{N}$ mineralization is difficult due to intercrossing effects of the variables involved in crop management, such as climatic conditions and soil type (Li et al., 2001; Fan et al., 2005a). It has been shown that a reliable method to determine potential $\mathrm{N}$ mineralization in rice paddy soils is anaerobic incubation because it adjusts to field conditions and flooding under which the crop develops; in addition, the continuity of $\mathrm{N}$ supplementation mainly depends on mineralized ammonium from the labile fraction of organic forms of $\mathrm{N}$ (Bushong et al., 2007; Rodriguez et al., 2008).

One more reason that supports the importance to predict $\mathrm{N}$ mineralization is to prevent excessive $\mathrm{N}$ fertilization, because of its environmental impact through the emission of greenhouse gases and pollution resulting from runoff and leaching (Zhang et al., 2004; Fan et al., 2005b; Su et al., 2005). Furthermore, while its cumulative effect negatively acts on soil $\mathrm{N}$ availability over time, this effect can be positive in the short term because a fraction of the $\mathrm{N}$ deposited in the soil every season gets available to the plants; thus, it also affects 
nutrient dynamics after each harvest (Clay and Clapp, 1990). Total mineralized $\mathrm{N}$ could be positively related to $\mathrm{N}$ fertilizer rates (Yan et al., 2006; Hirzel et al., 2012); if so, it will either result in a residual effect as part of the clay and soil $\mathrm{N}$ organic fraction (Jensen et al., 2000) or be retained in the soil microbial biomass (Jensen et al., 2000; Sainz et al., 2004). All the later suggest that a considerable portion of the $\mathrm{N}$ applied in previous season could be recovered in subsequent seasons and be estimated by methodologies that can be adjusted for each soil type for rice (Yan et al., 2006) and for maize (Zea mays L.) (Hirzel et al., 2007). In Chile, the rice crop or monocrop in a 2-yr rotation with natural pasture without irrigation leads to soil $\mathrm{N}$ accumulation that that could be used to optimize $\mathrm{N}$ fertilizers and to an environment friendly fertilization management (Hirzel et al., 2011). The objective of the present study was to generate and calculate an accurate index able to relate crop $\mathrm{N}$ uptake from previous $\mathrm{N}$ fertilization events and mineralized $\mathrm{N}$ in two rice paddy soils in Chile.

\section{MATERIALS AND METHODS}

\section{Soil $\mathbf{N}$ mineralization by anaerobic incubation}

Incubations from soil samples obtained in rice crop fields established on Alfisol and Vertisol orders, of Parral clay loam (fine, mixed, active, thermic Aquic Haploxeralfs) and Quella clay loam (fine, smectitic, thermic Aquic Durixererts) series, respectively (CIREN, 1983; USDA, 2010) fertilized with increasing $N$ rates $(0,80$, and $160 \mathrm{~kg} \mathrm{~N} \mathrm{ha}^{-1}$ ) during the previous season (2011-2012) (Hirzel and Rodríguez, 2013) were carried out in the Soils Laboratory of the Instituto de Investigaciones Agropecuarias INIA (Chillán, Chile) during the 20122013 season. Samples were collected in cores at 0 to $20 \mathrm{~cm}$ depth increment once the 2012-2013 season was over and 10 subsamples were considered for each experimental unit. The results of the physical and chemical characterization of the samples are shown in Table 1. A modified Waring and Bremner (1964) anaerobic incubation method was used to estimate soil $\mathrm{N}$ mineralization: $5 \mathrm{~g}$ soil and $12.5 \mathrm{~mL}$ distilled water were put in a $150 \mathrm{~mL}$ plastic container sealed with a stopper and incubated separately at two temperatures, 20 and 40 ${ }^{\circ} \mathrm{C}$ for periods of $0,7,14,21$, and $28 \mathrm{~d}$ in an incubator model FOC215E (Waring and Bremner, 1964; Hirzel et al., 2012). The ammonia $\mathrm{N}\left(\mathrm{N}_{-} \mathrm{NH}_{4}^{+}\right)$concentration in the extracts was determined by adding $12.5 \mathrm{~mL} 4 \mathrm{M}$ potassium chloride $(\mathrm{KCl})$ and shaking for $1 \mathrm{~h}$ (Mulvaney, 1996); it was then filtered with a Advantec 5C filter paper and $\mathrm{N}_{-} \mathrm{NH}_{4}{ }^{+}$was determined colorimetrically with a Skalar segmented flow spectrophotometer (Skalar SA 4000, Skalar Analytical B.V., Breda, The Netherlands).

\section{Nitrogen uptake and residual effect}

The field experiment was conducted in the 2012-2013
Table 1. Initial soil physical and chemical properties $(0$ to $20 \mathrm{~cm}$ depth).

\begin{tabular}{lcc}
\hline & \multicolumn{2}{c}{ Rice paddy soil } \\
\cline { 2 - 3 } Parameters & Alfisol & Vertisol \\
\hline Clay, \% & 34.1 & 36.1 \\
Silt, \% & 38.8 & 32.6 \\
Sand, \% & 27.1 & 31.2 \\
Bulk density, g cm-3 & 2.09 & 1.89 \\
Total porosity, \% & 22.3 & 28.7 \\
pH (soil:water 1:5) & 5.2 & 5.7 \\
Organic matter, $\mathrm{g} \mathrm{kg}^{-1}$ & 48.0 & 22.0 \\
EC, dS m-1 & 0.10 & 0.04 \\
Ratio C:N & 12.0 & 11.4 \\
Olsen P, mg kg-1 & 12.0 & 4.9 \\
Exchangeable K, cmol $\mathrm{kg}^{-1}$ & 0.26 & 0.17 \\
Exchangeable Ca, $\mathrm{cmol}_{\mathrm{c}} \mathrm{kg}^{-1}$ & 6.30 & 7.80 \\
Exchangeable Mg, cmol $\mathrm{kg}^{-1}$ & 2.30 & 3.26 \\
Exchangeable Na, cmol $\mathrm{kg}^{-1}$ & 0.30 & 0.26 \\
Exchangeable Al, cmol $\mathrm{kg}^{-1}$ & 0.12 & 0.02 \\
Available Fe, mg kg-1 & 266.0 & 47.5 \\
Available Mn, mg kg-1 & 189.0 & 77.6 \\
Available Zn, mg kg-1 & 2.3 & 0.6 \\
Available Cu, mg kg-1 & 5.1 & 3.6 \\
Available B, mg kg-1 & 0.19 & 0.05 \\
Available S, mg kg-1 & 32.0 & 1.0 \\
\hline
\end{tabular}

season without $\mathrm{N}$ fertilization. Soils were the same ones characterized for anaerobic incubation with clay loam, low permeability, and imperfect drainage. The area has a Mediterranean climate with high temperatures and low precipitation in summer and low temperatures and high precipitation in winter (Hirzel et al., 2007). Current agricultural practice in these sectors is irrigated rice between September and April. The experimental sites were divided in a complete block design with three treatments of residual $\mathrm{N}$ fertilization (fertilized in the 2011-2012 season) and four replicates. Each of the three experimental plots within the block measured $5 \times$ $3 \mathrm{~m}$. Experimental plots were previously tilled in winter with conventional tillage equipment and cultivated by optimizing agronomic practices for rice. The cultivar used was Zafiro-INIA, seeds were pre-germinated $2 \mathrm{~d}$ before sowing at a rate of $140 \mathrm{~kg} \mathrm{ha}^{-1}$. Soils were fertilized before sowing with $60 \mathrm{~kg} \mathrm{P}_{2} \mathrm{O}_{5}$ and $60 \mathrm{~kg} \mathrm{~K} \mathrm{~K}_{2} \mathrm{O}$ as triple superphosphate and potassium chloride, respectively. Plots were cultivated under traditional agronomic management to optimize crop growth in accordance with standard agronomic practices for rice crops in central Chile. Nitrogen (urea) was applied three times: $33 \%$ the day prior to sowing, $33 \%$ at tillering, and $34 \%$ at initial panicle (Hirzel et al., 2011).

The crop was harvested at the end of the season at grain maturity with $20 \%$ moisture (Hirzel et al., 2011); whole plant samples were collected from each plot (Yan et al., 2006) to determine total plant $\mathrm{N}$ concentration and DM production. Whole plant samples were collected from an area of $0.5 \mathrm{~m}^{2}$ in each experimental unit; this material was then dried, ground, sieved, analyzed by the macroKjeldahl procedure to determine total $\mathrm{N}$ concentration (Hirzel et al., 2012), and DM production was determined by weighing the ground dry material. Plant $\mathrm{N}$ uptake was calculated as the product of DM and plant $\mathrm{N}$ concentration 
for each treatment (Yan et al., 2006; Hirzel et al., 2007). Finally, $\mathrm{N}$ residual effect of the season was calculated as the difference between plant $\mathrm{N}$ absorption in each treatment fertilized in the previous season and the control (Sørensen and Amato, 2002).

\section{Ratio index for residual crop $\mathbf{N}$ uptake and residual $\mathbf{N}$ mineralization}

Mineralized N was correlated with crop N uptake through different combinations of temperature and time (Srpska and Sad, 2005; Yan et al., 2006), and the correlation values allowed determination of the most appropriate method (incubation time and temperature) for each soil; to this end, a linear mathematical model in the SAS simple regression function (Wilson et al., 1994; Sahrawat, 2006; Hirzel et al., 2012) and ANOVA were used. To determine the ratio index (Uptake Index) between crop $\mathrm{N}$ uptake from the residual effect of $\mathrm{N}$ fertilization and $\mathrm{N}$ mineralization in each type of soil (Sørensen and Amato, 2002), the following equation was used:

$\left.\begin{array}{r}\text { Uptake } \\ \text { Index }\end{array}=\frac{\begin{array}{c}\text { N Uptake } \\ \text { treatments with N }\end{array}}{\begin{array}{l}\text { N Uptake in control } \\ \text { without N }\end{array}}\right)$

A split-plot experimental design was used where the principal plot was the soil (2) and $\mathrm{N}$ rates (3) were the split-plots with three replicates for each experimental unit. Results were analyzed by ANOVA and the least significant difference (LSD) test $(\mathrm{P}=0.05)$ with the general model procedure of the SAS software (SAS Institute, Cary, North Carolina, USA).

\section{RESULTS AND DISCUSSION}

\section{Anaerobic incubations on soil $\mathbf{N}$ mineralization}

Mineralization of $\mathrm{N}-\mathrm{NH}_{4}{ }^{+}$is primarily influenced by soil type $(\mathrm{P}<0.05)$ and incubation time $(\mathrm{P}<0.01)$ at $20{ }^{\circ} \mathrm{C}$. However, there was a significant difference $(\mathrm{P}<0.01)$ at 40 ${ }^{\circ} \mathrm{C}$ only for incubation time, which reduces the sensitivity to detect differences between soils (Table 2). Equations and curves, adjusted to a quadratic model, represent the

Table 2. Analysis of variance for $\mathrm{N}-\mathrm{NH}_{4}{ }^{+}$mineralization obtained in two paddy rice soils fertilized with three $\mathrm{N}$ rates and incubated for 0 , $7,14,21$, and $28 \mathrm{~d}$ at 20 and $40^{\circ} \mathrm{C}$.

\begin{tabular}{lcc}
\hline & \multicolumn{2}{c}{ Temperature } \\
\cline { 2 - 3 } Source of variability & $20^{\circ} \mathrm{C}$ & $40^{\circ} \mathrm{C}$ \\
\hline Soil $^{1}$ & $*$ & $\mathrm{~ns}$ \\
Time $^{2}$ & $* *$ & $* *$ \\
N- rate & $*$ & $* *$ \\
Soil $\times$ Time & $*$ & $\mathrm{~ns}$ \\
Soil $\times$ N rate $(\mathrm{N})$ & $*$ & $* *$ \\
Time $\times$ N rate & $\mathrm{ns}$ & $\mathrm{ns}$ \\
Soil $\times$ Time $\times$ N rate & $\mathrm{ns}$ & $\mathrm{ns}$ \\
\hline
\end{tabular}

${ }^{* * * *}$ Significant at 0.05 and 0.01 probability levels, respectively. ns: nonsignificant.

${ }^{1}$ Two soil orders: Alfisol and Vertisol.

${ }^{2}$ Five incubation times: $0,7,14,21$, and $28 \mathrm{~d}$.

${ }^{3}$ Three $\mathrm{N}$ rates: 0,80 , and $160 \mathrm{~kg} \mathrm{ha}^{-1}$. evolution of $\mathrm{N}_{-} \mathrm{NH}_{4}{ }^{+}$mineralization in treatments that received different $\mathrm{N}$ rates in the previous season (Figure 1); they showed a similar pattern throughout the incubation period up to $28 \mathrm{~d}$ at 20 and $40{ }^{\circ} \mathrm{C}$. The highest level of $\mathrm{N}_{-} \mathrm{NH}_{4}{ }^{+}$mineralization recorded in Alfisol occurred with the $160 \mathrm{~kg} \mathrm{~N} \mathrm{ha}^{-1}$ rate applied in the previous season and, with the average of two temperatures, the value was 68.07 $\mathrm{mg} \mathrm{kg}^{-1}$ for $28 \mathrm{~d}$ of incubation, which was higher than control without $\mathrm{N}(\mathrm{P}<0.05)$ (Figure 1a). Mean mineralized $\mathrm{N}-\mathrm{NH}_{4}{ }^{+}$concentration in the Vertisol was $54.15 \mathrm{mg} \mathrm{kg}^{-1}$ at $160 \mathrm{~kg} \mathrm{~N} \mathrm{ha}^{-1}$ rate applied in the previous season for $21 \mathrm{~d}$ incubation (Figure 1b). The differences in the amount of mineralized $\mathrm{N}$ in both soils respond to higher $\mathrm{N}$ uptake of the previous season in Vertisol (Hirzel and Rodríguez, 2013) and to the dynamics of $\mathrm{N}_{-} \mathrm{NH}_{4}{ }^{+}$adsorption and desorption in the dominant type of clay (Montmorillonite) in the Vertisol under incubation conditions (Nieder et al., 2010), which in turn is mediated by soil biomass (Jensen et al., 2000; Sainz et al., 2004; Sahrawat, 2006) as well as the degree of $\mathrm{K}$ saturation (Table 1) in the intermediate layers of clay minerals (Nieder et al., 2010). The submerged condition of rice paddy soils is also a factor that influences the level of soil $\mathrm{N}-\mathrm{NH}_{4}{ }^{+}$mineralization; however, it can lead to contradictory conclusions about the extent of mineralization. According to several researchers, immobilization is less pronounced under non-flooding conditions (Chen et al., 1987). It is also reported that soils under flooding conditions significantly increase $\mathrm{N}-\mathrm{NH}_{4}{ }^{+}$ fixation in the soil (Stucki et al., 1984; Chen et al., 1987). As expected, mineralized $\mathrm{N}$ increased in both incubated soils along with the increased $\mathrm{N}$ fertilization rate used in the previous season. ANOVA corroborated this result of the experiment that indicates differences $(\mathrm{P}<0.05)$ with the control without $\mathrm{N}$ fertilization (Table 2). These data are consistent with studies conducted by several authors (Kolberg et al., 1999; Forge and Simard, 2001). Furthermore, in reference to an incubation experiment conducted in rice paddy soils at $40{ }^{\circ} \mathrm{C}$, Hirzel et al. (2012) indicate that $\mathrm{N}$ fertilization stimulates mineralization of native soil $\mathrm{N}$. This phenomenon is known as the 'priming' effect, which stimulates microorganisms to increase biomass development and increases mineralization of native soil OM (Fontaine et al., 2003; Conde et al., 2005). However, given that the fertilization had been applied in the previous season, this effect in increased mineralization mainly obeys the residual effect of $\mathrm{N}$ fertilization as pointed out by Yan et al. (2006) for rice and Hirzel et al. (2007) for maize.

\section{Nitrogen concentration in whole plant, DM production, and $\mathrm{N}$ uptake by the crop}

As was expected, plant DM production and $\mathrm{N}$ uptake values obtained in both locations were lower than values obtained by Peng et al. (2007), Huang et al. (2008), and Hirzel et al. (2012) (Table 3) although these authors conducted their studies by adding $\mathrm{N}$ in ranges similar 
(a)

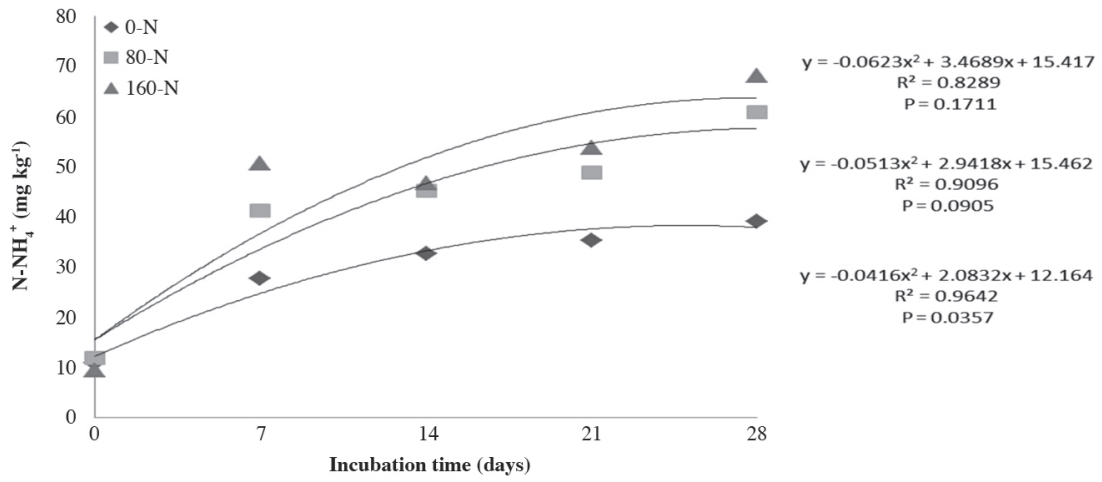

(b)

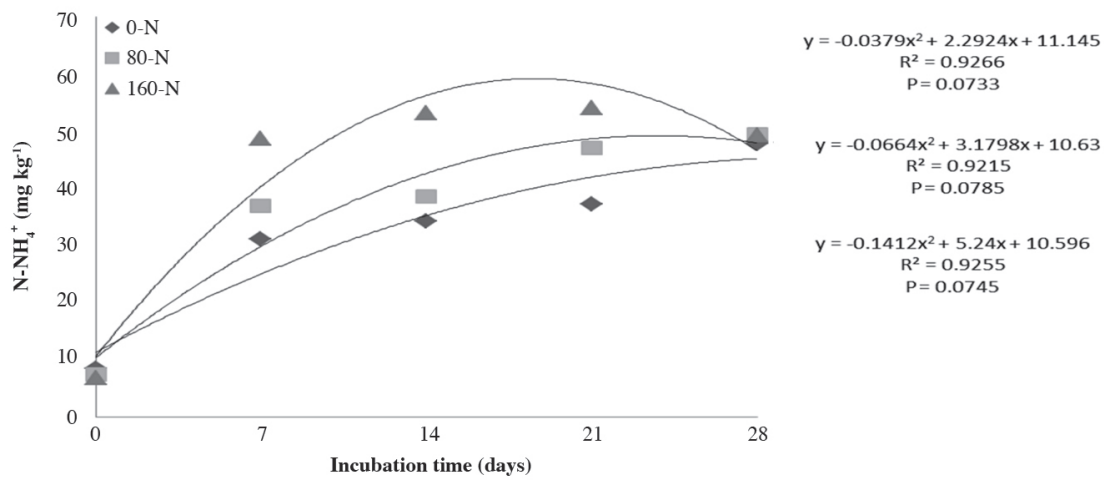

0-N: control without $\mathrm{N}$ fertilization, $80-\mathrm{N}$ : $80 \mathrm{~kg} \mathrm{~N}$ ha $^{-1} ; 160-\mathrm{N}$ : $160 \mathrm{~kg} \mathrm{~N} \mathrm{ha}^{-1}$.

Figure 1. Mean $\mathrm{N}-\mathrm{NH}_{4}{ }^{+}$concentration evolution by anaerobic incubation at 20 and $40{ }^{\circ} \mathrm{C}$ in two paddy rice soil: (a) Alfisol and (b) Vertisol.

to the rates used in the season in which this experiment received $\mathrm{N}$ fertilization. On the average, plant $\mathrm{N}$ concentration results were higher than those indicated by Hirzel et al. (2012) (Table 3). Previous publications have reported that most of the $\mathrm{N}$ in rice plants is taken up before anthesis, and up to $67 \% \mathrm{~N}$ uptake in vegetative parts at anthesis is translocated during the grain-filling stage (Ntanos and Koutroubas, 2002). There was significant relationship between DM accumulation after anthesis and $\mathrm{N}$ translocation of rice cultivars, suggesting that $\mathrm{N}$ translocated from vegetative organs played an important role in DM accumulation after anthesis. Therefore, an abundant amount of $\mathrm{N}$ translocated to the grain was necessary for Japonica rice to obtain high grain yields (Zhang et al., 2007). The highest DM production of the

Table 3. Nitrogen concentration, dry matter, and $\mathrm{N}$ uptake obtained in the field experiment with Alfisol and Vertisol rice paddy soils.

\begin{tabular}{lcccc}
\hline Soil & Treatments & $\begin{array}{c}\text { Whole plant } \mathrm{N} \\
\text { concentration }\end{array}$ & $\begin{array}{c}\text { Dry matter } \\
\text { production }\end{array}$ & $\begin{array}{c}\text { Whole plant } \\
\text { N uptake }\end{array}$ \\
\hline \multirow{3}{*}{ Alfisol } & $\mathrm{N}-0$ & $\mathrm{~g} \mathrm{~kg}^{-1}$ & $\mathrm{mg} \mathrm{ha}^{-1}$ & $\mathrm{~kg} \mathrm{ha}^{-1}$ \\
& $\mathrm{~N}-80$ & $7.1 \mathrm{a}$ & $5.72 \mathrm{~b}$ & $40.69 \mathrm{~b}$ \\
& $\mathrm{~N}-160$ & $7.0 \mathrm{a}$ & $9.34 \mathrm{a}$ & $65.31 \mathrm{a}$ \\
Vertisol & $\mathrm{N}-0$ & $7.3 \mathrm{a}$ & $10.26 \mathrm{a}$ & $74.58 \mathrm{a}$ \\
& $\mathrm{N}-80$ & $8.0 \mathrm{a}$ & $3.43 \mathrm{~b}$ & $26.82 \mathrm{~b}$ \\
& $\mathrm{~N}-160$ & $7.1 \mathrm{a}$ & $7.52 \mathrm{ab}$ & $55.14 \mathrm{ab}$ \\
& & $7.0 \mathrm{a}$ & $10.34 \mathrm{a}$ & $72.63 \mathrm{a}$ \\
\hline
\end{tabular}

Different letters for the same soil indicate significant differences according to LSD test $(\mathrm{P}<0.05)$.

N-0: 0 kg N ha' $a^{-1}$ N-80: $80 \mathrm{~kg} \mathrm{~N} \mathrm{ha}^{-1}$; N-160: $160 \mathrm{~kg} \mathrm{~N} \mathrm{ha}^{-1}$. three treatments was recorded in the Alfisol along with a lower plant $\mathrm{N}$ concentration (Table 3 ) associated with a dilution effect by remobilization of the element to the grain (Zhang et al., 2007; Hirzel et al., 2012). Plant N concentration (Table 3) was not affected by the $\mathrm{N}$ rates applied in the field $(\mathrm{P}>0.05)$ unlike the results found by some authors using different $\mathrm{N}$ rates (Matsunami et al., 2009; Taylaran et al., 2009; Hirzel and Rodríguez, 2013).

Nitrogen uptake in the Alfisol showed the highest levels in the two treatments where $\mathrm{N}$ fertilization was applied in the previous season $(\mathrm{P}<0.05)$ (Table 3$)$. In the Vertisol, the highest DM level was obtained in the treatments that received $\mathrm{N}$ in the previous season (Table 3 ) and there was no significant differences among them $(\mathrm{P}>0.05)$; this contrasts with the results found with $\mathrm{N}$ mineralization where differences were detected for the different rates applied in the previous season (Table 2). This is because the recovery of soil available $\mathrm{N}$ responds to descending increments of DM production when availability of this nutrient in the soil is increased (Vanotti and Bundy, 1994). In this soil, plant $\mathrm{N}$ concentration was not affected by $\mathrm{N}$ rates applied in the previous season $(\mathrm{P}>0.05)$. Nitrogen uptake of treatments evaluated in the Vertisol showed increases associated with the two $\mathrm{N}$ fertilizer rates used in the previous season and although these surpassed the control without $\mathrm{N}(\mathrm{P}<0.05)$, there were no differences among treatments that had received $\mathrm{N}(\mathrm{P}>0.05)$. This 
contrasts with the differences obtained for $\mathrm{N}$ mineralization (Table 2), an effect which was already explained.

\section{Correlation of soil $\mathbf{N}$ mineralization indexes with $\mathbf{N}$ uptake by plants}

The coefficients of determination $\left(\mathrm{R}^{2}\right)$ between mineralized $\mathrm{N}$ and plant $\mathrm{N}$ uptake under soil incubations at 20 and $40^{\circ} \mathrm{C}$ fluctuated between $0.20^{\text {ns }}$ and $0.73^{* *}$ for the Alfisol; for the Vertisol, results fluctuated between $0.34^{*}$ and $0.78^{* *}$ (Table 4). These values were generally lower than those obtained by Wilson et al. (1994) in a similar experiment of up to $14 \mathrm{~d}$ of anaerobic incubation.

The highest $\mathrm{R}^{2}$ at $20^{\circ} \mathrm{C}$ was recorded after $7 \mathrm{~d}\left(0.73^{* *}\right)$ and the highest coefficient at $40^{\circ} \mathrm{C}$ was obtained after 28 $\mathrm{d}$ with a value of $0.58^{* *}$ (Table 4 ). Regression coefficients for the Vertisol and Alfisol were the same but lower than values reported by Wilson et al. (1994). The highest $R^{2}$ for incubation at $20^{\circ} \mathrm{C}$ was $0.56^{* *}$ after $28 \mathrm{~d}$ and $0.78^{* * *}$ for incubation at $40{ }^{\circ} \mathrm{C}$ (Table 4). As pointed out by some authors (Srpska and Sad, 2005; Yan et al., 2006), these results show a close relationship between $\mathrm{N}$ mineralization under anaerobic conditions and $\mathrm{N}$ absorption by the rice crop and suggest that the anaerobic incubation procedure to estimate the residual value of $\mathrm{N}$ fertilization was at $20{ }^{\circ} \mathrm{C}$ for $7 \mathrm{~d}$ in Alfisol and $40{ }^{\circ} \mathrm{C}$ for $21 \mathrm{~d}$ in Vertisol. The value for Vertisol coincides with Hirzel et al. (2012), who indicate $\mathrm{R}^{2}=0.84^{* * *}$ that is highly significant for incubation at $40{ }^{\circ} \mathrm{C}$ in a Vertisol for $21 \mathrm{~d}$.

Figure 2 shows the linear model for the ratio between crop $\mathrm{N}$ uptake and $\mathrm{N}$ mineralization for the Alfisol using the method of the highest $\mathrm{R}^{2}=0.73^{* *}$ after $7 \mathrm{~d}$ of incubation at $20{ }^{\circ} \mathrm{C}$. For the Vertisol, values used were $\mathrm{N}$ mineralization obtained after $21 \mathrm{~d}$ of incubation at $40^{\circ} \mathrm{C}$ (Figure 3) and $\mathrm{R}^{2}=0.78^{* *}$. In general, a highly significant relationship was observed for either soil, which was adjusted with a linear model; it represents how $\mathrm{N}$ uptake depends on soil mineralized $\mathrm{N}$. However, to recommend a methodology for determining potentially mineralizable $\mathrm{N}$, a correlation between temperatures and incubation times for either soil would have been expected; moreover, it

Table 4. Regression coefficients between mineralized $\mathrm{N}$-ammonium in anaerobic conditions without shaking for different incubation times and total $\mathrm{N}$ uptake in rice crops for Alfisol and Vertisol rice paddy soils in Chile.

\begin{tabular}{lccc}
\hline & & \multicolumn{2}{c}{$\begin{array}{c}\text { Regression coefficient for a linear } \\
\text { mathematical model }\left(\mathrm{R}^{2}\right)\end{array}$} \\
\cline { 2 - 4 } Soil & $\begin{array}{c}\text { Incubation } \\
\text { time }(\mathrm{d})\end{array}$ & $20^{\circ} \mathrm{C}$ & $40^{\circ} \mathrm{C}$ \\
\hline Alfisol & 0 & $0.21 \mathrm{~ns}$ & $0.21 \mathrm{~ns}$ \\
& 7 & $0.74^{* *}$ & $0.41^{*}$ \\
& 14 & $0.59^{* *}$ & $0.32 \mathrm{~ns}$ \\
Vertisol & 21 & $0.22 \mathrm{~ns}$ & $0.31 \mathrm{~ns}$ \\
& 28 & $0.66^{* *}$ & $0.58^{* *}$ \\
& 0 & $0.34^{*}$ & $0.34^{*}$ \\
& 7 & $0.41^{*}$ & $0.51^{* *}$ \\
& 14 & $0.42^{*}$ & $0.50^{* *}$ \\
& 21 & $0.50^{* *}$ & $0.77^{* *}$ \\
& 28 & $0.56^{* *}$ & $0.31 \mathrm{~ns}$
\end{tabular}

*, ${ }^{* *}$ Significant at 0.05 and 0.01 probability levels, respectively. ns nonsignificant.

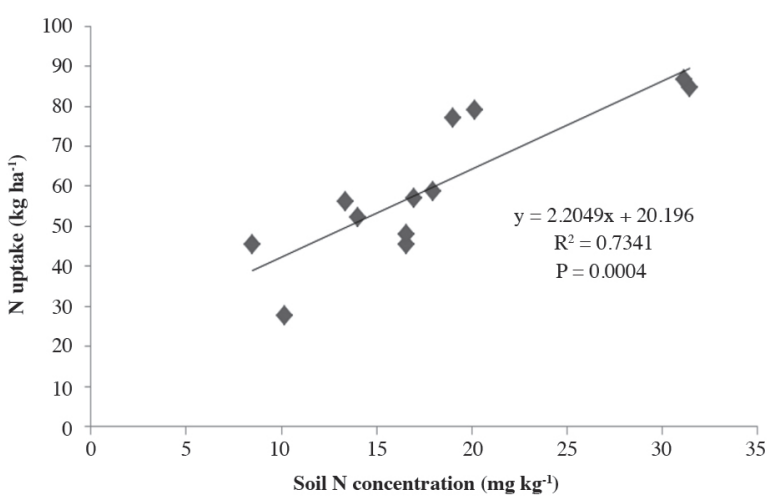

Figure 2. Relationship between $\mathbf{N}$ uptake and soil available $\mathbf{N}$ as a residual effect of $\mathbf{N}$ fertilization applied in an Alfisol rice paddy soil incubated for $7 \mathrm{~d}$ at $20^{\circ} \mathrm{C}$.

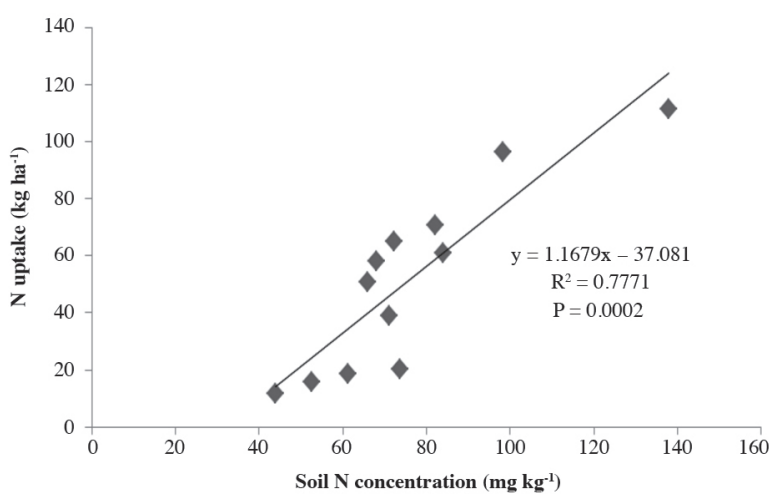

Figure 3. Relationship between $\mathbf{N}$ uptake and soil available $\mathbf{N}$ as a residual effect of $\mathbf{N}$ fertilization applied in a Vertisol rice paddy soil incubated for $21 \mathrm{~d}$ at $40^{\circ} \mathrm{C}$.

would be necessary to work with a higher number of soils and seasons under study.

Considering that the control did not receive any $\mathrm{N}$, the relationship between crop $\mathrm{N}$ uptake from the previous $\mathrm{N}$ fertilization and soil mineralized $\mathrm{N}$ was 2.2049 and 1.1679 (slopes of the straight line) $\mathrm{kg} \mathrm{N}$ absorbed for each $\mathrm{mg}$ mineralized $\mathrm{N} \mathrm{kg}^{-1}$ in Alfisol and Vertisol, respectively (Figures 2 and 3). This indicates that the Alfisol exhibited a higher liberation of residual $\mathrm{N}$ to the crop compared with the Vertisol, which is associated to the type of clay prevailing in both soils (Nieder et al., 2010) and the dynamics of $\mathrm{N}$ in each soil in the presence of plants where the delivery capacity of soil $\mathrm{N}$ could be higher than the result generated by an analysis of available $\mathrm{N}$ prior to crop establishment as pointed out by Fernández (1995) and Hirzel et al. (2007) for maize in the absence of fertilization.

\section{Uptake index from the residual effect of $\mathbf{N}$ fertilization and $\mathrm{N}$ residual mineralization}

Results indicate that residual fertilization produced increased mineralization between 6.1 and $13.3 \mathrm{mg} \mathrm{N}^{-\mathrm{NH}_{4}}{ }^{+}$ $\mathrm{kg}^{-1}$ in Alfisol, whereas this increase in Vertisol fluctuated between 18.4 and $28.0 \mathrm{mg} \mathrm{N}-\mathrm{NH}_{4}{ }^{+} \mathrm{kg}^{-1}$ in both cases 
compared with the control without N. Crop N uptake as a residual effect of applied $\mathrm{N}$ was between 29.3 and 33.9 $\mathrm{kg} \mathrm{N} \mathrm{ha}^{-1}$ in Alfisol and 28.3 and $45.8 \mathrm{~kg} \mathrm{~N}^{-1}$ in Vertisol compared with the control in both cases, no significant difference existed that corroborates significance between their means $(\mathrm{P}>0.05)$. The ratio index between crop $\mathrm{N}$ uptake capacity from the residual effect of the previous fertilization and soil mineralized $\mathrm{N}$ fluctuating between 4.8 and 2.5 for N-80 and N-160 respectively for Alfisol, and 1.5 and 1.6 for $\mathrm{N}-80$ and $\mathrm{N}-160$ respectively for Vertisol (Table 5).

The relationship between $\mathrm{N}$ residual uptake and residual $\mathrm{N}$ mineralizable concentration from the previous fertilization is shown in Figures 4 and 5 for Alfisol and Vertisol, respectively. This relationship indicates that the crop in the Alfisol can uptake 1.3402 and in the Vertisol $0.7351 \mathrm{~kg} \mathrm{~N}$ for each $\mathrm{mg}$ mineralized $\mathrm{N} \mathrm{kg}^{-1}$. By discounting $\mathrm{N}$ mineralization in soil that did not receive $\mathrm{N}$ in the previous season, a new adjustment is attained between the relationship of $\mathrm{N}$ absorption and soil $\mathrm{N}$ mineralization (difference between the slopes of each straight line) in both the Alfisol (Figures 2 and 4) and Vertisol (Figures 3 and 5), which results in values of 0.86 and $0.43 \mathrm{~kg} \mathrm{~N}$ absorbed for each $1 \mathrm{mg} \mathrm{kg}^{-1}$ of soil mineralized $\mathrm{N}$ for Alfisol and Vertisol, respectively. In practical terms, once mineralized $\mathrm{N}$ is determined in anaerobic incubations, savings of 0.86 and $0.43 \mathrm{~kg} \mathrm{~N}$ can be generated when applying it to the rice crop for each $1 \mathrm{mg} \mathrm{N} \mathrm{kg}^{-1}$ mineralized with respect to the

Table 5. Residual uptake index from residual $\mathrm{N}$ uptake and residual mineralized $\mathbf{N}$ for Alfisol and Vertisol paddy rice soils.

\begin{tabular}{lcccc}
\hline Soil & Treatments & $\begin{array}{c}\text { Residual } \\
\text { uptake }\end{array}$ & $\begin{array}{c}\text { Residual } \\
\text { mineralized }\end{array}$ & $\begin{array}{c}\text { Uptake } \\
\text { index }\end{array}$ \\
\hline \multirow{4}{*}{ Alfisol } & $\mathrm{N}-80$ & $\mathrm{~kg} \mathrm{ha}^{-1}$ & $\mathrm{mg} \mathrm{kg}^{-1}$ & \\
& $\mathrm{~N}-160$ & $29.3 \mathrm{a}$ & $6.1 \mathrm{a}$ & 4.8 \\
Vertisol & $\mathrm{N}-80$ & $33.9 \mathrm{a}$ & $13.3 \mathrm{a}$ & 2.5 \\
& $\mathrm{~N}-160$ & $28.3 \mathrm{a}$ & $18.4 \mathrm{a}$ & 1.5 \\
& & $45.8 \mathrm{a}$ & $28.0 \mathrm{a}$ & 1.6 \\
\hline
\end{tabular}

Different letters for the same soil indicate significant differences according to LSD test $(\mathrm{P}<0.05)$.

N-80: $80 \mathrm{~kg} \mathrm{~N} \mathrm{ha}^{-1}$; N-160: $160 \mathrm{~kg} \mathrm{~N} \mathrm{ha}^{-1}$

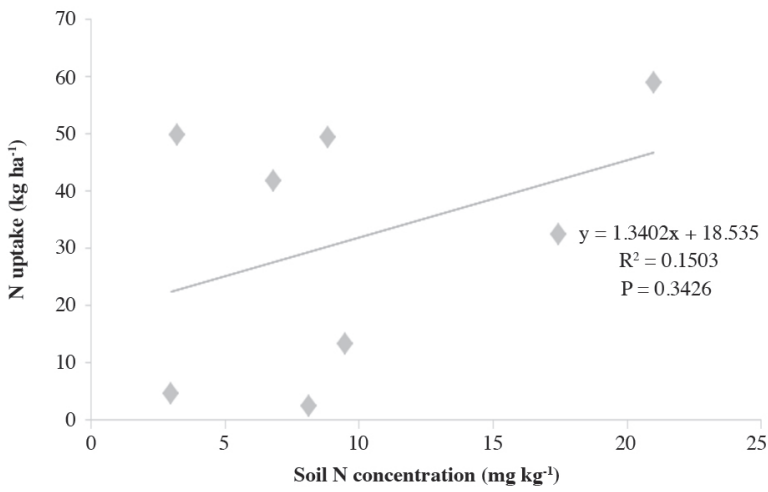

Figure 4. Relationship between residual $\mathrm{N}$ uptake and soil available $\mathbf{N}$ for treatments fertilized with $\mathbf{N}$ in the previous season and the control without $\mathrm{N}$ in an Alfisol rice paddy soil incubated for $7 \mathrm{~d}$ at $20{ }^{\circ} \mathrm{C}$.

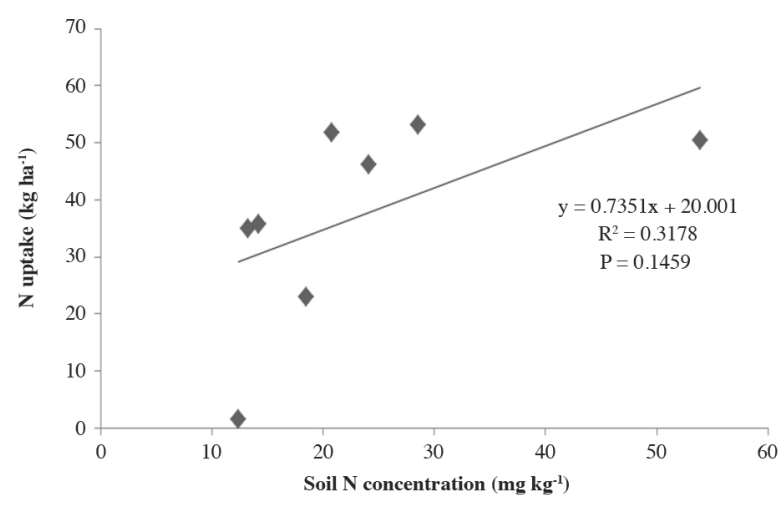

Figure 5. Relationship between residual $\mathbf{N}$ uptake and soil available $\mathbf{N}$ for treatments fertilized with $\mathrm{N}$ in the previous season and the control without $N$ in a Vertisol rice paddy soil incubated for $21 \mathrm{~d}$ at $40^{\circ} \mathrm{C}$.

calculated or reference rate to be applied for the Alfisol and Vertisol used in this experiment. These results contribute to adjusting $\mathrm{N}$ rates used in the rice crop, improve use efficiency of this nutrient, and reduce the environmental impact (Wang et al., 2001; Zhang et al., 2004; Fan et al., 2005a; Su et al., 2005).

\section{CONCLUSIONS}

We have shown that the index of $\mathrm{N}$ uptake, as a result of the residual effect from the previous fertilization, allows determining the quantity of $\mathrm{N}$ that can be saved for the following season. Soils incubated at different time lapses and temperatures generate values of mineralizable $\mathrm{N}$. Therefore, the correlation between $\mathrm{N}$ uptake and mineralized $\mathrm{N}$ are good measures to estimate the best incubation methodology that reflects field conditions. Thus, these indexes will greatly contribute to save amounts of $\mathrm{N}$ to each $1 \mathrm{mg} \mathrm{N} \mathrm{kg}^{-1}$ mineralized for the Alfisol and Vertisol, respectively.

\section{ACKNOWLEDGEMENTS}

This study was funded by FONDECYT 11110232 Project of the Comisión Nacional de Investigación Científica (CONICYT), Chile.

\section{LITERATURE CITED}

Alvarado, J.R., y S. Hernaiz. 2007. Antecedentes generales sobre el arroz en Chile. p. 7-20. In R. Alvarado (ed.) Arroz manejo tecnológico. Instituto de Investigaciones Agropecuarias INIA, Chillán, Chile.

Bushong, J.T., R.J. Norman, W.J. Ross, N.A. Slaton, C.E. Wilson, and E.E. Gbur. 2007. Evaluation of several indices of potentially mineralizable soil nitrogen. Communications in Soil Science and Plant Analysis 38:2799-2813.

Chen, R.J., W. Zhang, W. Guo, and W. Chen. 1987. N fertilizer (urea) top dressed on unsaturated soil and deep-placed using reflooding water. International Rice Research Newsletter 12:35-36.

CIREN. 1983. Descripciones de suelos: Estudio agrológico complementario VII Región. Centro de Información de Recursos Naturales (CIREN), Santiago, Chile. 
Clay, D.E., and C.E. Clapp. 1990. Mineralization of low C-to-N ratio corn residue in soils fertilized with $\mathrm{NH}$; fertilizer. Soil Biology \& Biochemestry 22:355-360.

Conde, E., M. Cardenas, A. Ponce-Mendoza, M.L. Luna-Guido, C. Cruz-Mondragón, and L. Dendooven. 2005. The impacts of inorganic nitrogen application on mineralization of ${ }^{14} \mathrm{C}$-labelled maize and glucose, and on priming effect in saline alkaline soil Soil Biology \& Biochemistry 37:681-691.

Fan, M., R. Jiang, X. Liu, F. Zhang, S. Lu, X. Zeng, et al. 2005b. Interactions between non-flooded mulching cultivation and varying nitrogen inputs in rice-wheat rotations. Field Crops Research 91:307-318.

Fan, X.H., D.X. Lin, M. Shen, and S.W. Qin. 2005a. Characteristics of mineralization and nitrification in the calcareous soils from a long-term fertilization experimental field. Acta Pedologica Sinica 42:340-343 (in Chinese).

Fernández, M. 1995. Fertilización nitrogenada y su eficiencia en maíz de grano. Simiente 65:122-132.

Fontaine, S., A. Mariotti, and L. Abbadie. 2003. The priming effect of organic matter: A question of microbial competition? Soil Biology \& Biochemistry 35:837-843.

Forge, T.A., and S.W. Simard. 2001. Short-term effects of nitrogen and phosphorus fertilizers on nitrogen mineralization and trophic structure of the soil ecosystem in forest clear cuts in the southern interior of British Columbia. Canadian Journal of Soil Science 81:11-20.

Hirzel, J., K. Cordero, C. Fernández, J. Acuña, M. Sandoval, and E. Zagal. 2012. Soil potentially mineralizable nitrogen and its relation to rice production and nitrogen needs in two paddy rice soils of Chile. Journal of Plant Nutrition 35:3, 396-412.

Hirzel, J., A. Pedreros, and K. Cordero. 2011. Effect of nitrogen rates and split nitrogen fertilization. Chilean Journal of Agricultural Research 71:1-8.

Hirzel, J., and F. Rodríguez. 2013. Increasing nitrogen rates in rice and its effect on plant nutrient composition and nitrogen apparent recovery. Chilean Journal of Agricultural Research 73:385-390.

Hirzel, J., I. Walter, P. Undurraga, and M. Cartagena. 2007. Residual effects of poultry litter on silage maize (Zea mays L.) growth and soil properties derived from volcanic ash. Soil Science and Plant Nutrition 53:480-488.

Honeycutt, C.W. 1999. Nitrogen mineralization from soil organic matter and crop residues: Field validation of laboratory predictions. Soil Science Society of America Journal 63:134-141.

Huang, J., F. He, K. Cui, R. Buresh, B. Xu, W. Gong, et al. 2008. Determination of optimal nitrogen rate for rice varieties using a chlorophyll meter. Field Crops Research 105:70-80.

Jensen, L.S., I.S. Pedersen, T.B. Hansen, and N.E. Nielsen. 2000 Turnover and fate of $15 \mathrm{~N}$-labelled cattle slurry ammonium- $\mathrm{N}$ applied in the autumn to winter wheat. European Journal of Agronomy 12:23-35.

Jing, Q., B. Bouman, H. van Keulen, H. Hengsdijk, W. Cao, and T. Dai. 2008. Disentangling the effect of environmental factors on yield and nitrogen uptake of irrigated rice in Asia. Agricultural System 98:177-188.

Kolberg, R.L., D.G. Westfall, and G.A. Peterson. 1999. Influence of cropping intensity and nitrogen fertilizer rates on in situ nitrogen mineralization. Soil Science Society of America Journal 63:129-134.

Li, G.C., X.G. Han, J.H. Huang, and J.W. Tang. 2001. A review of affecting factors of soil nitrogen mineralization in forest ecosystems. Acta Ecologica Sznica 21:1187-1195 (in Chinese).

Matsunami, M., T. Matsunami, and M. Kokubun. 2009. Growth and yield of new rice for Africa (NERICAs) under different ecosystems and nitrogen levels. Plant Production Science 12:381-389.

Mulvaney, L.R. 1996. Nitrogen inorganic forms. p. 1123-1184. In J.M. Bartels (ed.) Methods of Soil Analysis. Part 3: Chemical Methods. American Society of Agronomy, Madison, Wisconsin, USA.

Nieder, R., D.K. Benbi, and H.W. Scherer. 2010. Fixation and defixation of ammonium in soils: a review. Biology and Fertility of Soils 47:1-14.
Ntanos, D.A., and S.D. Koutroubas. 2002. Dry matter and N accumulation and translocation for Indica and Japonica rice under Mediterranean conditions. Field Crops Research 74:93-101.

ODEPA. 2013. Cultivos anuales: Superficie, producción y rendimientos. Oficina de Estudios y Políticas Agrarias (ODEPA), Santiago, Chile. Available at http://www.odepa.cl/cultivosanuales-superficie-produccion-y-rendimientos-4/ (accessed 12 May 2013)

Peng, X-L., Y-Y. Liu, S-G. Luo, L-C. Fan, T-X. Song, and Y-W. Guo 2007. Effects of site-specific nitrogen management on yield and dry matter accumulation of rice from cold areas of northeastern China. Agricultural Sciences in China 6:715-723.

Rodriguez, A., W. Hoogmoed, and L. Brussaard. 2008. Soil quality assessment in rice production systems: Establishing a minimum data set. Journal of Environmental Quality 37:623-630.

Sahrawat, K. 2006. Organic matter and mineralizable nitrogen relationships in wetland rice soils. Communications in Soil Science and Plant Analysis 37:787-796.

Sainz, H.R., H.E. Echeverría, and P.A. Barbieri. 2004. Nitrogen balance as affected by application time and nitrogen fertilizer rate in irrigated no-tillage maize. Agronomy Journal 96:1622-1631.

Sørensen, P., and M. Amato. 2002. Remineralisation and residual effects of $\mathrm{N}$ after application of pig slurry to soil. European Journal of Agronomy 16:81-95.

Srpska, M., and N. Sad. 2005. Aerobic and anaerobic incubation biological indexes of soil nitrogen. Proceedings of the Serbian Cultural Society of Natural Sciences 109:45-57.

Stucki, J.W., D.C. Golden, and C.B. Roth. 1984. Effects of reduction and reoxidation of structural iron on clay swelling. Clays and Clay Minerals 32:350-356.

Su, C.G., B. Yin, Z.L. Zhu, and Q.R. Shen. 2005. Gaseous loss of nitrogen from fields and wet deposition of atmospheric nitrogen and their environmental effects. Soils 37:113-120 (in Chinese).

Taylaran, R., S. Ozawa, N. Miyamoto, T. Ookawa, T. Motobayashi, and T. Hirasawa. 2009. Performance of a high-yielding modern rice cultivar Takanari and several old and new cultivars grown with and without chemical fertilizer in a submerged paddy field. Plant Production Science 12:365-380.

USDA. 2010. Spanish keys to soil taxonomy. $11^{\text {th }}$ ed. United States Department of Agriculture USDA, Natural Resources Conservation Service, Washington, DC., USA.

Vanotti, M.B., and L.G. Bundy. 1994. An alternative rationale for corn nitrogen fertilizer recommendations. Journal of Production Agriculture 7:243-249.

Wang, G., A. Dobermann, C. Witt, Q. Sun, and R. Fu. 2001 Performance of site-specific nutrient management for irrigated rice in southeast China. Agronomy Journal 93:869-878.

Waring, S.A., and J.M. Bremner. 1964. Ammonium production in soil under waterlogged conditions as an index of $\mathrm{N}$ availability. Nature 201:951-952.

Wienhold, B. 2007. Comparison of laboratory methods and an in situ method for estimating nitrogen mineralization in an irrigated silt-loam soil. Communications in Soil Science and Plant Analysis 38:1721-1732.

Wilson, C.E., R.J. Norman, B.R. Wells, and M.D. Correll. 1994 Chemical estimation of nitrogen mineralization in paddy rice soils. II. Comparison to greenhouse availability indices Communications in Soil Science and Plant Analysis 25:591-604.

Yan, D-Z., D-J. Wang, R-J. Sun, and J-H. Lin. 2006. N Mineralization as affected by long-term $\mathrm{N}$ fertilization and its relationship with crop N uptake. Pedosphere 16:125-130.

Zhang, Y.M., D.L. Chen, J.B. Zhang, R. Edis, C.S. Hu, and A.N Zhu. 2004. Ammonia volatilization and denitrification losses from an irrigated maize-wheat rotation field in the north China plain. Pedosphere 14:533-540.

Zhang, Y.H., J.B. Fan, Y.L. Zhang, D.S. Wang, Q.W. Huang, and Q.R. Shen. 2007. N Accumulation and translocation in four Japonica rice cultivars at different $\mathrm{N}$ rates. Soil Science Society of China 17:792-800. 